\title{
Partisipasi masyarakat dalam pengembangan organisasi wahana kesejahteraan sosial berbasis masyarakat (WKSBM)
}

\author{
Shobichatul Aminah ${ }^{1 *}$, Iis Prasetyo ${ }^{1}$ \\ ${ }^{1}$ Program Studi Pendidikan Luar Sekolah, Program Pascasarjana, Universitas Negeri \\ Yogyakarta. Jalan Colombo No. 1, Karang Malang, Yogyakarta 55281, Indonesia \\ * Corresponding Author. Email: aminahvonin@gmail.com \\ Received: 23 December 2017; Revised: 19 March 2018; Accepted: 28 May 2018
}

\begin{abstract}
Abstrak
Penelitian ini bertujuan untuk mendeskripsikan: (1) tahapan partisipasi masyarakat dalam pengembangan WKSBM melalui komunikasi multitrack, (2) bentuk partisipasi masyarakat dalam pengembangan WKSBM melalui komunikasi multitrack, dan (3) faktorfaktor yang mempengaruhi partisipasi masyarakat dalam pengembangan WKSBM melalui komunikasi multitrack. Penelitian ini menggunakan analisis penelitian deskriptif. Hasil penelitan ini adalah: (1) tahapan partisipasi masyarakat dalam pengembangan WKSBM melalui model komunikasi multitrack adalah penilaian, penyusunan rencana dan desain, pelaksanaan komunikasi dan evaluasi, (2) bentuk-bentuk partisipasi masyarakat dalam pengembangan WKSBM melalui komunikasi multitrack adalah kontribusi, tanggung jawab dan peran, (3) faktor-faktor yang mempengaruhi partisipasi masyarakat dalam Pengembangan WKSBM melalui komunikasi multitrack adalah faktor internal dan eksternal. Faktor internal yang mempengaruhi adalah usia, pekerjaan dan komunikasi. Faktor eksternal yang muncul yaitu tanggapan dari masyarakat, kebijakan pemerintah dan kebermanfaatan WKSBM untuk masyarakat.
\end{abstract}

Kata Kunci: komunikasi multitrack, partisipasi masyarakat, WKSBM

\section{Community participation in organization development of society- based social welfare (WKSBM)}

\begin{abstract}
This study aims to describe: (1) the steps of community participation in the development of WKSBM through multitrack communication, (2) forms of community participation in the development of WKSBM through multitrack communication, (3) affecting factors of community participation in developing WKSBM through multitrack communication. This research were used qualitative research with description method. The results of this research were: (1) the steps community participation in the development of WKSBM through multitrack communication, (2) forms of community participation in the development of WKSBM through multitrack communication, and (3) affecting factors of community participation in the development of WKSBM through multitrack communication are internal and external factors. Internal factors that affect the age, work and communication. External factors that arise are the responses from the community, government policies and the usefulness of WKSBM for the community.

Keywords: community participation, multitrack communication, WKSBM (society-based social welfare

How to Cite: Aminah, S., \& Prasetyo, I. (2018). Partisipasi masyarakat dalam pengembangan organisasi wahana kesejahteraan sosial berbasis masyarakat (WKSBM). JPPM (Jurnal Pendidikan dan Pemberdayaan Masyarakat), 5(1), 61-73. doi:http://dx.doi.org/10.21831/jppm.v5i1.17531

doi

http://dx.doi.org/10.21831/jppm.v5i1.17531
\end{abstract}




\section{JPPM (Jurnal Pendidikan dan Pemberdayaan Masyarakat), 5 (1), 2018 - 62}

Shobichatul Aminah, Iis Prasetyo

\section{PENDAHULUAN}

Permasalahan sosial merupakan masalah yang tidak mudah diatasi. Masalah sosial tidak datang dengan sendirinya, banyak aspek yang mempengaruhi seperti aspek, ekonomi, budaya, politik dan lain-lain. Permasalahan sosial tidak hanya dilihat secara kasat mata, perlu adanya analisis untuk mengetahui permasalahan sosial yang tengah terjadi dalam masyarakat.

Permasalahan sosial yang terjadi di Daerah Istimewa Yogyakarta (DIY) menurut Dinas Sosial DIY terdapat beberapa isu strategis. Masalah sosial yang menjadi isu strategis di DIY dalam (Dinas Sosial Daerah Istimewa Yogyakarta, 2016) seperti: (a) kemiskinan, (b) keterlantaran, (c) ketunaan sosial, (d) kecacatan, (e) korban bencana alam dan bencana sosial."

Masalah sosial yang menjadi fokus permasalahan dalam jurnal ini yaitu masalah yang ada pada seseorang dan kelompok. Seseorang atau kelompok tersebut diistilahkan sebagai Penyandang Masalah Kesejahteraan Sosial (PMKS). Pengurangan angka PMKS merupakan tugas dari organisasi sosial. Adanya PMKS juga berhubungan dengan jumlah keluarga miskin. Menurut data dari Padukuhan Kromodangsan per Desember tahun 2016 jumlah keluarga miskin yang ada sebanyak 64 keluarga dari 284 keluarga. Keluarga miskin dapat menjadi Penyandang Masalah Kesejahteraan sosial (disingkat PMKS) jika terdapat lansia atau anak dalam keluarga miskin terlantar secara ekonomi. Tercatat, jumlah PMKS yang ada di Dusun Kromodangsan, Kelurahan Lumbungrejo, Kecamatan Tempel mencapai 41 orang PMKS.

Tingginya angka PMKS membuat pemerintah maupun lembaga sosial bertanggung jawab secara serius untuk menangani masalah ini. Pemerintah dapat mengatasi hal tersebut melalui kerja sama dengan masyarakat.

Organisasi sosial dibentuk untuk menangani permasalahan sosial. Masalahmasalah sosial yang ada di Kromodangsan hampir sama dengan masalah sosial yang ada di daerah lain. (dalam wawancara dengan kepala dukuh) "Masalah yang ada di
Dusun Kromodangsan seperti, Perceraian, KDRT (kekerasan dalam rumah tangga), anak putus sekolah." Hal ini tentu menjadi alasan perlu adanya organisasi sosial. Masalah sosial bisa diatasi dengan baik jika masyarakat sadar sosial. Kegiatan sosial yang dilakukan melalui organisasi RT, yang ada di Dusun Kromodangsan baru berjalan di RT o4 saja. Sedangkan 3 RT lainnya yaitu RT o1, 02, 03 belum maksimal.

Wahana Kesejahteraan Sosial Berbasis Masyarakat (WKSBM) adalah alat, wadah, saran maupun media yang digunakan oleh masyarakat untuk melaksanakan usaha kesejahteraan sosial secara berkelanjut. Wahana ini berupa jaringan kerja kelembagaan sosial komunitas lokal baik yang tumbuh melalui proses alamiah dan tradisional maupun Iembaga yang sengaja dibentuk untuk mensinergikan pelaksanaan tugas di bidang usaha kesejahteraan sosial seperti kelompok arisan, kelompok usaha bersama, lumbung desa dan nilai budaya lokal.”

Kelompok yang dibentuk untuk membantu permasalahan sosial ini memiliki tujuan untuk mensinergikan pelaksanaan tugasnya bersama kelompok-kelompok masyarakat lain yang sesuai bidangnya atau diluar bidangnya. Di Dusun Kromodangsan Kelurahan Lumbungrejo belum memiliki organisasi sosial akan tetapi memiliki potensi. Tokoh-tokoh masyarakat memiliki kemauan untuk membentuk sebuah organisasi sosial dan bisa bekerja sama dengan lembaga-lembaga lain. Sayangnya, belum dilaksanakan karena kesibukan dari masyarakatnya.

Dusun Kromodangsan yang memang wilayahnya perkotaan dan bermata pencaharian yang heterogen. Selain potensi di atas, ada pula potensi sebagai sumber daya manusia yang akan ikut serta dalam WKSBM. Masyarakat yang memiliki berbagai potensi diaharapkan dapat berperan. Sebagaimana tokoh yang telah ditemui peneliti adalah aktivis dan berpendidikan manajemen dan sosial. sedangkan potensi sebagai sumber pendukungnya adalah masyarakat yang mampu secara ekonomi dan perhatian pada masalah sosial yang ada. Perbedaan profesi antar warga menjadi sebab sulitnya koordinasi dalam pelaksanaan sosialisasi maupun pertemuan. 


\section{JPPM (Jurnal Pendidikan dan Pemberdayaan Masyarakat), 5 (1), 2018 - 63}

Shobichatul Aminah, Iis Prasetyo

Penelitian ini bertujuan untuk mewujudkan partisipasi masyarakat pada organisasi sosial di Dusun Kromodangsan Kelurahan Lumbungrejo Kecamatan Tempel. Partisipasi masyarakat sangat penting bagi organisasi untuk mewujudkan tujuan orga-nisasi. Tanpa adanya partisipasi dari masyarakat tentu organisasi tidak berjalan. Partisipasi ini dapat berupa fisik dan psikis. Terdapat pemahaman bahwa Salah satu upaya dalam menciptakan partisipasi masyarakat yang tinggi diupayakan tumbuh kembangnya organisasi atau kelembagaan nonformal masyarakat (Anwas, 2013, p. 75)

Partisipasi yang diharapkan adalah partisipasi sosial dari masyarakat. Tidak ada konsep yang jelas mengenai partisipasi masyarakat, tetapi ada pendapat bahwa partisipasi masyarakat adalah proses dimana orang sebagai anggota masyarakat dapat menyampaikan pendapat dan membuat keputusan, implementasi dan saling berbagi manfaat "Community participation is a process where in people in the community have access to decision-making, implementation and benefit sharing. But, the concept of community participation is contested, and there is no clear and commonly agreed definition" (Huq, 1977, p. 44).

Partisipasi menurut Adi (2002, p. 110) pada dasarnya partisipasi adalah keikutsertaan atau keterlibatan masyarakat dalam proses identifikasi masalah, pengambilan keputusan, pelaksanaan juga keterlibatan dalam evaluasi pengatasan masalah. Pada penelitian ini keterlibatan masyarakat terdapat pada proses tersebut. masyarakat ikut terlibat dalam proses komunikasi yaitu asesmen komunikasi, penyusunan desain dan rencana komunikasi, pelaksanaan komunikasi hingga monitoring dan evaluasi komunikasi. Komunikasi ini digunakan sebagai alat untuk pengembangan organisasi WKSBM.

Masyarakat berpartisipasi aktif tidak hanya melalui organisasi dengan mengemukakan pendapat tetapi juga melakukan perencanaan. Perencanaan yang dibuat untuk mencapai tujuan. Agar partisipasi masyarakat terus berlanjut, perencanaan disusun dalam program berkelanjutan. Salah satu unsur pembangunaan baru adalah partispasi masyarakat. "Partisipasi masyara-kat dalam perencanaan dan pelaksanaan pembangunan biasanya dibarengi dengan desentralisasi kegiatan-kegiatan tertentu di pedesaan" (Rogers, 1976, p. 190).

Masyarakat yang terlibat adalah masyarakat setempat. Pembangunan masyarakat perlu adanya keterlibatan masyarakat. keterlibatan masyarakat disini adalah keterlibatan masyarakat berdasarkan wilayah tempat tinggal. “...Community participattion implies the participation of the disempowered. Ideally, it would involve people who have little or no access to basic education as a community, geographical area or gender." (Ramachandran, 2003, p. 57).

Ada beberapa gagasan penting partisipasi. Partisipasi menurut Davis \& Newstrom (2012, pp. 199-200) memiliki keterlibatan tiga gagasan penting, diantara adalah keterlibatan moral dan emosional, motivasi kontribusi, dan tanggung jawab.

Penelitian yang dilakukan oleh Penelitian pemberdayaan kelompok tersebut diawali dengan kondisi peserta yang belum diberlakukan dan sesudah diberikan perlakuan. Materi pemberdayaan dengan konsep dengan ketahanan pangan masyarakat. Indikasi dalam pemberdayaan forum yakni; tingkat perlindungan sosial bagi kelompok PMKS, tingkat partisipasi masyarakat, tingkat pengendalian konflik sosial.

\section{METODE}

Untuk mengkaji permasalahan pada penelitian ini digunakan metode penelitian kualitatif deskriptif. Geertz (Ratna, 2010, p. 338) juga menyatakan bahwa "deskripsi merupakan uraian padat, thick description. Dengan deskripsi dimaksudkan agar pembaca seolah-olah ikut merasakan apa yang dirasakan oleh peneliti." Pengertian tersebut menunjukkan bahwa penelitian kualitatif dengan metode deskripsi adalah metode yang tepat untuk penelitian tentang partisipasi masyarakat dalam pengembangan organisasi WKSBM melalui komunikasi multitrack.

Penelitian tentang partisipasi masyarakat dalam pengembangan organisasi WKSBM melalui komunikasi multitrack diungkapkan dan diuraikan secara mendalam. Uraian penelitian deskripsi ini berisi 
kata-kata dan hasil pengamatan yang dilakukan pada subyek penelitian.

Tempat pada penelitian ini dilakukan di Dusun Kromodangsan, Kelurahan Lumbungrejo, Kecamatan Tempel, Kabupaten Sleman. Penelitian ini dilakukan pada setiap aktivitas kegiatan masyarakat yang berkaitan dengan kegiatan organisasi WKSBM. Penelitian deskripsi ini telah dilakukan di Dusun Kromodangsan Kelurahan Lumbungrejo Kecamatan Tempel memerlukan waktu penelitian 5 bulan. Penelitian ini dimulai pada bulan Februari 2017 hingga Juni 2017.

Teknik pengumpulan data yang digunakan dalam penelitian deskriptif kualitatif ini adalah dengan teknik wawancara, observasi dan dokumentasi. Analisis data yang digunakan melalui tiga tahap meliputi; pengumpulan data atau reduksi data, display data dan penarikan kesimpulan.

Subjek penelitian ini adalah warga dan para tokoh masyarakat dengan jumlah 35 orang yang dipilih sebagai calon pengurus WKSBM di Dusun Kromodangsan, Kelurahan Lumbungrejo, Kecamatan Tempel, Kabupaten Sleman.

Penentuan sumber data yang digunakan menggunakan teknik snowball sampling. Teknik snowball sampling juga dilakukan dengan teknik penentuan sampel diambil berdasarksan sistem network (jejaring). Sumber data pada penelitian deskriptif ini adalah:

Pertama, pendiri WKSBM "Kroda Mandiri", yaitu pihak atau warga Dusun Kromodangsan yang memulai pembentukkan WKSBM di Kromodangsan. Informasi yang ingin didapat dari informan adalah proses komunikasi multitrack, partisipasi masyarakat dan faktor-faktor partisipasi. Komunikasi multirack memiliki tujuan yaitu untuk mengembangkan WKSBM di Kromodangsan.

Kedua, pengurus WKSBM "Kroda Mandiri", yaitu pihak sebagai pengurus WKSBM setelah dilakukan komunikasi. Informasi yang ingin diketahui dari informan adalah keterlibatan dan partisipasi pengurus dalam pengembangan WKSBM "Kroda Mandiri”.

Ketiga, donatur WKSBM "Kroda Mandiri”, yaitu pihak sebagai warga Kromodang- san yang berpartisipasi atau berkontribusi dana untuk WKSBM “Kroda Mandiri”. Informasi yang ingin diketahui dari informan adalah keterlibatan dan partisipasi donatur dalam kontribusi dana untuk WKSBM "Kroda Mandiri".

Keempat, warga yang belum terlibat dalam WKSBM "Kroda Mandiri". Informasi yang ingin diketahui dari warga yang belum terlibat adalah pengetahuan tentang WKSBM. Selain itu, ingin mengetahui tanggapan dari warga yang belum terlibat mengenai WKSBM.

Sumber data yang telah disebutkan diharapkan mampu memberikan informasi yang dibutuhkan dalam penelitian. Teknik Pengumpulan data menggunakan pendekatan kualitatif, teknik pengumpulan data dalam penelitian ini adalah observasi, wawancara dan dokumentasi.

Observasi adalah teknik pengumpulan data yang dilakukan peneliti untuk mengamati hal-hal yang berkaitan dengan ruang, tempat, pelaku, kegiatan, benda-benda, waktu, peristiwa, tujuan dan perasaan (Djunaidi \& Almanshur, 2012). Teknik Pengumpulan data menggunakan observasi, peneliti dapat mengamati gejala-gelaja peristiwa, perilaku, waktu dan perasaan.

Pengamatan dilakukan untuk mengamati aktivitas masyarakat dalam partisipasi organisasi sosial WKSBM melalui komunikasi multirack. Selain itu, peneliti mengamati masyarakat dalam sosialisasi organisasi sosial. Untuk membantu teknik observasi ini peneliti menggunakan catatan-catatan lapangan mengenai perubahan-perubahan yang terjadi di lapangan.

Wawancara kualitatif merupakan salah satu teknik pengumpulan data yang dapat digunakan peneliti untuk mendapat informasi mendalam. Wawancara merupakan teknik pengumpulan data yang dilakukan oleh peneliti dengan bertanya secara langsung pada subyek penelitian. Pedoman wawancara menggunakan teknik wawancara terpimpin.

Teknik analisis data dalam penelitian kualitatif ini menggunakan teknik dari Miles dan Hubermas (Mukhtar, 2013, p. 135). Terdapat empat macam teknik yaitu; pengumpulan data, reduksi data, model data (data 


\section{JPPM (Jurnal Pendidikan dan Pemberdayaan Masyarakat), 5 (1), 2018 - 65}

Shobichatul Aminah, Iis Prasetyo

display), dan penarikan/verifikasi kesimpulan.

Pengumpulan data merupakan tahap analisis yang pertama dilakukan. Data yang dikumpulkan berdasarkan hasil penelitian melalui wawancara, observasi dan dokumentasi.

Reduksi data merupakan teknik analisis yang bertujuan untuk memilih pokok bahasan. Mengfokuskan pada hal-hal penting dan membuang hal yang tidak perlu. Proses reduksi data adalah menyesuaikan dan mengelompokkan informasi dari informan. Langkah-langkah reduksi berupa perbaikan atau penejelasan, pengelompokkan dan peringkasan data. Hal tersebut dilakukan agar mempermudah peneliti dalam melakukan analisis.

Analisis setelah melakukan reduksi data adalah display data. Display data adalah tahap penyajian data yang telah di pilah dan kategorikan dalam bentuk narasi.tahap ini akan menentukan kesimpulan berdasarkan informasi yang diperoleh. Oleh karena itu peneliti harus menyajikan data yang telah direduksi secara sistematis.

Penarikan kesimpulan adalah teknik ketiga dalam penelitian kualitatif. Penarikan kesimpulan pada penelitian ini difokuskan pada partisipasi masyarakat dalam pengembangan WKSBM melalui komunikasi multitrack. Penarikan kesimpulan pada penelitian yang telah dilakukan adalah tentang tahapan partisipasi, bentuk-bentuk partisipasi dan faktor-faktor yang mempengaruhi partisipasi masyarakat dalam pengembangan organisasi WKSBM melalui komunikasi multitrack.

Uji keabsahan dalam penelitian ini menggunakan triangulasi data. Triangulasi merupakan merupakan gabungan dari berbagai metode yang dipakai untuk mengkaji fenomena. Penelitian ini menggunakan triangulasi sumber, metode dan teknik. Triangulasi merupakan penggunaan berbagai metode pengumpulan data. Triangulasi digunakan agar memperkaya penelitian dan memiliki hasil yang kredibilitas.

\section{HASIL DAN PEMBAHASAN}

Organisasi WKSBM merupakan organisasi sosial yang bergerak dalam mengatasi masalah sosial di masyarakat. "Wahana
Kesejahteraan Sosial Berbasis Masyarakat (WKSBM) adalah sistem kerja sama antar keperangkatan pelayanan sosial di akar rumput yang terdiri atas usaha kelompok, lembaga maupun jaringan pendu-kungnya." (Dinas Sosial Daerah Istimewa Yogyakarta, 2016).

WKSBM dibentuk dari berbagai unsur yang ada di masyarakat. Organisasi ini melibatkan potensi dan sumber yang ada di dalam dusun maupun sekitar dusun. Potensi dan sumber ini disebut sebagai PSKS. Potensi dan Sumber kesejahteraan Sosial. PSKS ini adalah WKSBM itu sendiri karena kesukarelawaannya untuk mengatasi permasalahan sosial.

Mengembangkan organisasi sosial perlu partisipasi masyarakat. Meningkatkan partisipasi masyarakat pada organisasi sosial tentu tidak mudah. Proses ini membutuhkan waktu yang cukup lama dan perlu perencanaan yang matang. Oleh karena itu, peningkatan partisipasi masyarakat memiliki beberapa tahap komunikasi di dalamnya terdapat model komunikasi multitrack.

Setiap tahap komunikasi terdapat assesment atau penilaian terlebih dahulu sebelum menyusun rencana komunikasi. Setelah desain dan strategi komunikasi dibuat kemudian dimplementasikan. Komunikasi tidak berhenti disitu saja, perlu adanya evaluasi dan monitoring setelah program dilaksanakan.

Hasil penelitian dapat diketahui bahwa partisipasi masyarakat dalam pengembangan organisasi WKSBM muncul melalui komunikasi multitrack. Hasil dari penelitian ini adalah tahapan, bentuk dan faktor-faktor yang mempengaruhi partisipasi masyarakat dalam pengembangan organisasi.

\section{Tahapan Partisipasi Masyarakat dalam Pengembangan WKSBM Melalui Model Komunikasi Multitrack}

Organisasi WKSBM merupakan organisasi sosial yang bergerak dalam mengatasi masalah sosial di masyarakat. "Wahana Kesejahteraan Sosial Berbasis Masyarakat (WKSBM) adalah sistem kerja sama antar keperangkatan pelayanan sosial di akar rumput yang terdiri atas usaha kelompok, lembaga maupun jaringan pendukungnya. 


\section{JPPM (Jurnal Pendidikan dan Pemberdayaan Masyarakat), 5 (1), 2018 - 66}

Shobichatul Aminah, Iis Prasetyo

Pengembangan organisasi dapat terwujud karena partisipasi masyarakat. partisipasi masyarakat terdapat tiga tahap partisipasi.

Tahapan partisipasi masyarakat dalam pengembangan WKSBM melalui komunikasi multitrack terdiri dari tiga tahap partisipasi. Komunikasi pertama bertujuan sebagai bentuk rekruitmen pengurus. Komunikasi kedua bertujuan sebagai bentuk sosialisasi tujuan WKSBM kepada masyarakat. kemudian, sosialisasi ketiga adalah bentuk pelaksanaan kegiatan WKSBM. Setiap komunikasi terdapat empat langkah komunikasi.

\section{Partisipasi Masyarakat dalam Pembentukan Organisasi}

Tahap partisipasi yang pertama adalah keterlibatan masyarakat dalam pembentukkan organisasi. Masyarakat dilibatkan dalam kepengurusan. Tahap partisipasi ini memiliki empat langkah komunikasi yang diikuti calon pengurus. Langkah komunikasi mulai dari asesmen masalah, menyusun strategi dan desain, implementasi, dan evaluasi komunikasi.

Penilaian yang dilakukan dimulai dari analisis masalah sosial yang ada di Kromodangsan. Selain masalah sosial juga dianalisis masalah karena tidak berlangsungnya organisasi sosial yang ada di Dusun Kromodangsan. Masalah sosial yang ada di Dusun Kromodangsan menjadi pertimbangan untuk membentuk organisasi WKSBM. Hal ini sesuai dengan isu strategis yang ada DIY. Permasalahan sosial yang terjadi di DIY menurut Dinas Sosial Daerah Istimewa Yogyakarta (2016) terdapat beberapa isu strategis. Masalah sosial yang menjadi isu strategis di DIY seperti: (a) kemiskinan, (b) keterlantaran, (c) ketunaan sosial, (d) kecacatan, (e) korban bencana alam dan bencana social (Dinas Sosial Daerah Istimewa Yogyakarta, 2016). Sedangkan di Dusun Kromodangsan masih ada masalah sosial seperti lansia terlantar, kemiskinan, kekerasan, dan lain-lain.

Strategi dan desain yang disusun pada komunikasi 1 adalah; (1) mengundang 12 tokoh masyarakat dan dari unsur masingmasing ketua RT (Rukun Tetangga), (2) membentuk pengurus organisasi WKSBM dan Pemberian nama WKSBM, (3) menyu- sun rencana dan program bersama anggota organisasi, (4) komunikasi yang dilaksanakan dengan komunikasi dialog dan monolog.

Tabel 1. Implementasi Komunikasi Pertama

\begin{tabular}{ll}
\hline Tema & $\begin{array}{l}\text { Pembentukan pengurus } \\
\text { WKSBM }\end{array}$ \\
\hline Tujuan & Membentuk Pengurus \\
& WKSBM \\
\hline Target dan & Tokoh masyarakat, \\
Indikator & Terbentuk pengurus \\
keberhasilan & WKSBM: Sekretaris, \\
& Bendahara, humas, dll \\
\hline Materi & Tentang tujuan WKSBM \\
& dan manfaat Organisasi \\
& sosial WKSBM \\
\hline Metode & Pemaran dan diskusi \\
\hline Instrumen & Notulen \\
\hline Susunan acara & Pembukaan \\
& Penjelasan tentang \\
& pengertian WKSBM. \\
& Diskusi tentang nama \\
& organisasi. \\
& Membentuk pengurus \\
& WKSBM. \\
\hline
\end{tabular}

Implementasi komunikasi dimulai dari penguatan pengurus dengan cara pembentukan pengurus. Pengurus dibentuk dari tokoh-tokoh masyarakat dengan jumlah 12 orang. Sedangkan hasil evaluasi pada komunikasi ini adalah masih awal dan kurang optimal dari masyarakat. Namun sudah ada yang dapat bergabung sebagai pengurus dan memiliki tujuan yang sama.

\section{Partisipasi Masyarakat dalam Sosialisasi Organiasi}

Tahap kedua dari partisipasi masyarakat adalah sosialisasi organisasi. Sosialisasi WKSBM dilakukan agar masyarakat tahu dan berpartisipasi dalam WKSBM. Tahap kedua ini pengurus yang telah terbentuk melakukan sosialisasi WKSBM menggunakan komunikasi multitrack.

Langkah pertama pengurus melakukan asesmen pada komunikasi sebelumnya. Asesmen dilakukan berdasarkan kondisi bahwa masyarakat belum mengetahui tentang WKSBM "Kroda Mandiri". Komunikasi tentang WKSBM sebelumnya masih pada tahap sosialisasi kepada beberapa tokoh saja.

Strategi dan desain dalam komunikasi ketiga disusun oleh peneliti beserta pengu- 
rus. Pertemuan ini sebagai tindak lanjut dari komunikasi kedua. Pertemuan ini mengundang pengurus WKSBM. Agar pengurus dapat hadir maka hari pertemuan adalah hari dimana pengurus dapat hadir seluruhnya. Pertemuan didesain dengan metode diskusi. Diskusi sebagai komunikasi dialog, lebih efektif daripada hanya monolog saja. Pertemuan ini membutuhkan tanggapan, kritik dan saran dari peserta pertemuan.

Perencanaan komunikasi kepada masyarakat harus mengandung informasiinformasi yang dapat menarik masyarakat. Penelitian dalam jurnal yang disusun oleh Panasyuk \& Nabiev, (2016) berisi studi mengenai interaksi proses sosial. Interaksi tersebut terdapat perencanaan strategis, proses pembelajaran, penjelasan pengetahuan yang kreatif. Interaksi tersebut digunakan agar komunikasi dapat tercapai yaitu pesan dapat tersampaikan dan dipahami oleh sasaran.

Tabel 2. Implementasi Komunikasi Kedua

\begin{tabular}{ll}
\hline Tema & Sosialisasi WKSBM \\
\hline Tujuan & $\begin{array}{l}\text { Mensosialisasi WKSBM, } \\
\text { Pemantapan Anggota, } \\
\text { menyusun program }\end{array}$ \\
\hline Target dan & Tokoh masyarakat dari \\
Indikator & beberapa unsur masyarakat: \\
keberhasilan & Ketua RT o1,o2,o3 dan o3, \\
& Ketua Takmir Masjid, Ketua \\
& LPMD dan kader kesehatan. \\
\hline Materi & Dihadiri 3o orang \\
\hline Metode & Pentang WKSBM \\
\hline Instrumen & Notulen \\
\hline Susunan acara & a) Pembukaan dan tanya jawab \\
& b) Sambutan Kepala Dukuh \\
& c) Sambutan Peneliti \\
& d) Sambutan Ketua WKSBM \\
& e) Materi Narasumber \\
& f) Tanya Jawab \\
& g) Musyawarah dipimpin \\
\hline
\end{tabular}

Hasil dari monitoring dan evaluasi tersebut yaitu pada pertemuan kedua. Hasil dari evaluasi adalah WKSBM perlu mengadakan pertemuan rutin dan melaksanakan kegiatan sosial. Setelah diadakan pertemuan tersebut dilaksanakan kegiatan selanjutnya sebagai hasil dari pertemuan komunikasi ketiga. Agar organisasi tetap berjalan maka direncanakan kegiatan selanjutnya.

\section{Partisipasi Masyarakat dalam Pelaksana- an Organisasi}

Tahap partisipasi ketiga adalah pelaksanaan organisasi. Pengurus mulai melaksanakan kegiatan organisasi. Tentu pada tahap ini terdapat komunikasi. Komunikasi pada pelaksanaan organisasi juga memiliki empat langkah komunikasi.

Langkah asesmen dilakukan oleh pengurus tentang permasalan sosial yang terjadi di masyarakat. Kemudian, langkah selanjutnya penyusunan strategi dan desain kegiatan organisasi. Langkah berikutnya adalah implementasi rencana kegiatan sosial.

Langkah terakhir ialah monitoring dan evaluasi. Pengurus melakukan monitoring dan evaluasi pada imlementasi komunikasi ketiga. Pertemuan rutin ini bertujuan agar terwujudnya partisipasi pengurus dalam evaluasi program. Selain itu ada banyak hal perlu didiskusikan bersama pengurus harian terkait keaktifan pengurus lain dan bagaimana solusinya. Strategi komunikasi yang digunakan adalah dialog. Diskusi ini membuat komunikasi antar pengurus lebih efektif. Pengurus dapat saling memberi informasi dan masalah-masalah yang terjadi di Kromodangsan.

Tahapan partisipasi penelitian ini sejalan dengan penelitian yang dilakukan oleh Prasetyo (2015) tentang partisipasi sosial dalam pembangunan pariwisata. Tahap partisipasi dalam pembangunan pariwisata terdapat dua tahap yaitu tahap perencanaan, implementasi dan evaluasi. Pada tahap perencanaan ada pengambilan keputusan yang dilakukan secara diskusi. Sedangkan pada tahap evaluasi penelitian pada pengembangan WKSBM dilaksanakan di setiap tahap partisipasi. Komunikasi adalah aspek pentik penting pada setiap tahapan partisipasi.

\section{Bentuk-Bentuk Partisipasi Masyarakat dalam Pengembangan WKSBM melalui Komunikasi Multitrack}

Peningkatan partisipasi lebih efektif menggunakan komunikasi multitrack. Komunikasi multitrack harus melibatkan masyarakat sebagai pelaku. Oleh sebab itu, secara langsung maupun tidak langsung 
masyarakat sebagai pengurus terlibat. Partisipasi yang muncul setelah tindakan adalah patisipasi dalam mengungkapkan pendapat, berkontribusi dana, tenaga dan sarana. Selain itu, pengurus telah melaksankan tugas dan peran masing-masing melalui sikap dan tanggunjawab.

Bentuk-bentuk partisipasi masyarakat terdapat beberapa aspek yaitu; aspek kontribusi, tanggung jawab dan sikap. Pada aspek kontribusi terdapat empat bentuk kontribusi yaitu; kontribusi tenaga, dana, sarana dan pendapat. Bentuk partisipasi adalah tanggung jawab pengurus terhadap organisasi. Tanggungjawab yang ditunjukkan oleh masyarakat sebagai pengurus sudah sesuai tugas dan peran masing-masing. Kemudian partisipasi masyarakat yang ketiga ialah sikap. Sikap yang ditunjukkan masyarakat terhadap WKSBM terdapat sikap positif dan negatif. Sikap tersebut ditunjukkan pada saat sosialisasi bahwa sasaran ada yang bersedia bergabung dan tidak.

Kontribusi tenaga menjadi kontribusi pertama dalam pengembangan organisasi. Beberapa warga yang bergabung menjadi pengurus awal secara sukarela memberikan waktunya untuk WKSBM. Mulai dari awal pembentukkan hingga berjalannya kegiatan sosial, pengurus mempersiapkan segala sesuatu yang dibutuhkan. Kontribusi tenaga ditunjukkan pada saat pengurus mendistribusikan kotak penggalangan dana.

Selain kontribusi tenaga, juga terdapat kontribusi dana. Suatu organisasi sosial, dana meruapakan aspek penting untuk keberlangsungan organisasi. Adanya WKSBM bisa menjadi tempat atau wadah yang tepat untuk menyalurkan dana. Bermanfaat untuk warganya sendiri juga menjadi alasan bagi beberapa untuk berdonasi. Informan bersedia menjadi donatur karena ingin menyalurkan atau memberi sebagian sedekahnya kepada masyarakat terutama masyarakat Kromodangsan.

Pengalangan dana sebagai bentuk usaha pengurus untuk mempertahankan keuangan yang nantinya akan diberikan kepada masyarakat yang membutuhkan. Kontribusi lain yang muncul dalam pengembangan organisasi adalah kontribusi sarana. Tentu saja tanpa sarana kegiatan komunikasi tidak dapat berjalan dengan baik.

Kebutuhan sarana tentu diperlukan dalam proses komunikasi. Sarana yang diperlukan dalam proses komunikasi bisa berasal dari mana saja. Namun, pada penelitian ini masyarakat juga berkontribusi dalam bentuk sarana tanpa mengaharap imbalan. Berikut ini adalah hasil pengamatan kegiatan pengurus WKSBM.

Pertemuan adalah media sosialisasi WKSBM kepada masyarakat. Sarana tentu dibutuhkan untuk memperlancar acara. Setiap kegiatan pertemuan diadakan sarana yang digunakan adalah tempat dan sound system. Sarana tersebut merupakan kontribusi masyarakat yang memiliki andil dalam pengembangan organisasi WKSBM.

Partisipasi yang kedua adalah bentuk sikap masyarakat. sikap masyarakat dapat tercermin dari wawancara seorang warga yang bukan pengurus WKSBM. Pendapat tersebut dapat menjadi energi yang positif untuk WKSBM. Meskipun tidak bergabung menjadi pengurus AM mendukung kegiatan tersebut sebagai kegiatan yang positif.

Sikap warga dalam pertemuan tersebut menunjukkan bahwa ada sikap yang mendukung dari masyarakat. Sikap yang dimunculkan warga tersebut menjadi energi positif bagi pengurus WKSBM sehingga pengurus mendapatkan masukan untuk tujuan kedepan.

Partisipasi selanjutnya adalah partisipasi dalam bentuk tanggung jawab. Tanggung jawab merupakan hal penting dari pengurus untuk menjalankan organisasi. Tanggung jawab yang ditunjukkan oleh pengurus WKSBM "Kroda Mandiri” adalah tanggung jawab berdasarkan tugas masingmasing.

Bentuk-bentuk partisipasi juga dikaji dalam penelitian yang dilakukan oleh Hermawan \& Suryono (2016) dalam jurnal yang berjudul "Partisipasi Masyarakat dalam Penyelenggaraan Program-Program Pusat Kegiatan Belajar Mengajar Ngudi Kapinteran" Bentuk partisipasi masyarakat terbagi dalam dua bentuk meliputi; (a) fisik yaitu material dan tenaga, dan (b) non fisik yaitu ide. Bentuk partisipasi dibagi menjadi dua yaitu partisipasi fisik dan non fisik. Pene- 


\section{JPPM (Jurnal Pendidikan dan Pemberdayaan Masyarakat), 5 (1), 2018 - 69}

Shobichatul Aminah, Iis Prasetyo

litian ini menjelaskan lebih rinci tentang bentuk-bentuk partisipasi masyarakat dalam pengembangan WKSBM.

Setiap tahap komunikasi menunjukkan kontribusi dari masyarakat. masyarakat yang bergabung dibagi menjadi dua unsur yaitu; pengurus dan donatur. Pengurus maupun donatur memiliki keterlibatan yang berbeda sehingga bentuk partisipasi yang ditunjukkan juga berbeda.

Aspek yang pertama adalah kontribusi. Kontribusi terdapat empat jenis kontribusi, diantaranya kontrbusi tenaga, dana, sarana dan pendapat. Aspek-aspek partisipasi masyarakat tentu melibatkan seseorang untuk berkontribusi. Partisipasi merupakan keterlibatan orang-orang dalam kelompok. Seperti yang dikatakan oleh Davis \& Newstrom (2012, p. 198) bahwa partisipasi adalah keterlibatan mental dan emosional orang-orang dalam kelompok yang mendorong mereka untuk berkontribusi kepada tujuan kelompok dan berbagi tanggung jawab pencapaian tujuan itu.

Kontribusi yang diberikan oleh masyarakat menjadi pengaruh besar pada pengembangan WKSBM "Kroda Mandiri". Kontribusi yang muncul sebagai bentuk partisipasi masyarakat dalam pengembangan WKSBM adalah kontribusi tenaga, dana, sarana dan pendapat. Selain pengurus, masyarakat yang mendapatkan sosialisasi WKSBM juga ikut berkontribusi.

Komunikasi tahap pertama peserta yang telah dipilih yang merupakan tokoh masyarakat. Partisipasi yang muncul dari peserta tersebut adalah kontribusi berupa pendapat, sarana. Sedangkan dalam keorganisasian telah terbentuk struktur organisasi sehingga peserta berpartisipasi dalam kepengurusan WKBM.

Partisipasi yang muncul pada komunikasi tahap kedua ini adalah peserta dapat mengemukakan pendapat, menyusun kegiatan, menyediakan sarana, memiliki struktur organisasi dan anggota mengetahui tugas masing-masing.

Partisipasi yang muncul pada komunikasi tahap ketiga ini adalah peserta dapat mengemukakan pendapat, menyusun kegiatan, menyediakan sarana, memiliki struktur organisasi dan anggota melaksanakan tugas masing-masing. selain itu beberapa warga selain pengurus ikut serta sebagai pengurus.

Bentuk partisipasi masyarakat bermacam-macam dalam pengembangan WKSBM di kromodangsan. Partisipasi masyarakat dalam pengembangan organisasi WKSBM muncul secara bertahap. Pelaksanaan komunikasi multitrack dari awal asesmen hingga evaluasi, masyarakat berpartisipasi dalam berbagai aspek. Aspek-aspek partisipasi masyarakat ialah aspek kontribusi, aspek sikap dan aspek tanggung jawab. Selajan dengan Partisipasi menurut Davis \& Newstrom (2012, pp. 199-200) memiliki keterlibatan tiga gagasan penting, diantara adalah:

\section{Keterlibatan Moral dan Emosional}

Keterlibatan ini bukan bersifat fisik tetapi keterlibatan anggota secara psikologis. Keterlibatan Secara moral dan emosional ini dapat berupa pendapat, ide dan lain-lain. Keterlibatan secara moral maupun emosional dari masyarakat belum terlibat namun keterlibatan dalam berpendapat sudah terlihat.

\section{Motivasi Kontribusi}

Gagasan kedua dalam partisipasi adalah motivasi kontribusi. Seseorang memiliki motivasi dan dapat memotivasi agar orang lain berkontribusi dalam organisasi. Kontribusi yang dibutuhkan adalah kontribusi anggota untuk mencapai tujuan.

\section{Tanggung Jawab}

Gagasan ketiga adalah mendorong orang untuk menerima tanggung jawab. Tanggung jawab dari anggota suatu organisasi merupakan aspek penting bagi organisasi. Tanpa adanya tanggung jawab maka organisasi tidak berjalan ssesuai rencana.

Bentuk-bentuk partisipasi pada penelitian ini berbeda dengan pendapat di atas. Keterlibatan secara moral dan emosional belum terlihat, namun sikap masyarakat sudah muncul sebagai bentuk partisipasi.

Partisipasi masyarakat dalam proses pengembangan masyarakat terdapat beberapa bentuk. Bentuk partisipasi masyarakat yang muncul diantaranya; kontribusi, sikap dan tanggung jawab. Partisipasi kontribusi 


\section{JPPM (Jurnal Pendidikan dan Pemberdayaan Masyarakat), 5 (1), 2018 - 70}

Shobichatul Aminah, Iis Prasetyo

sendiri memiliki empat bentuk yaitu; kontribusi berupa tenaga, dana, sarana dan pendapat.

Faktor-faktor yang Mempengaruhi Partisipasi Masyarakat dalam Pengembangan WKSBM melalui Komunikasi Multitrack.

Faktor yang mempengaruhi partisipasi masyarakat dibagi menjadi dua, yaitu; faktor internal dan eksternal. Faktor internal yang mempengaruhi partisipasi masyarakat adalah faktor usia, pendidikan, pekerjaan dan komunikasi. Sedangkan faktor ekternal adalah kebijakan pemerintah, tanggapan masyarakat dan kebermanfaatan WKSBM dalam kehidupan sosial ekomoni di Kromodangsan. Faktor internal adalah faktor yang berasal dari dalam organisasi WKSBM. Faktor internal yang mempengaruhi partisipasi masyarakat adalah faktor usia, pekerjaan dan komunikasi. Sedangkan faktor eksternal muncul dari luar. Pihak pemerintah dan narasumber sebagai sumber informasi, memberikan pengetahuan tentang WKSBM.

Faktor-faktor yang mempengaruhi partisipasi masyarakat dikemukakan oleh Suroso, Hakim, \& Noor (2014) bahwa terdapat beberapa faktor internal dan eksternal yang diuji menunjukkan bahwa faktor usia, komunikasi dan kepemimpinan mempunyai hubungan dengan partisipasi masyarakat.

\section{Faktor Internal}

Faktor internal yang mempengaruhi partisipasi masyarakat adalah faktor usia, pekerjaan dan komunikasi. Rata-rata usia yang bergabung menjadi pengurus adalah usia produktif. Sedangkan usia yang telah lanjut bergabung sebagai donatur saja. Faktor pekerjaan juga mempengaruhi partisipasi karena pekerjaan yang tidak bisa ditinggalkan oleh beberapa pengurus. Kemudian, komunikasi dalam organisasi tentu sangat mempengaruhi partisipasi. Komunikasi dalam pengembangan organisasi dilakukan terus-menerus. Komunikasi yang muncul adalah komunikasi dialog dan monolog terjadi secara informal maupun formal. Hal yang berbeda dari penelitian oleh Hermawan \& Suryono (2016) adalah pendidikan tidak menjadi pengaruh partisipasi masyarakat. pendidikan yang dimiliki oleh pengurus beraneka ragam.

\section{Faktor Eksternal}

Faktor eksternal adalah kebijakan pemerintah, tanggapan masyarakat dan kebermanfaatan WKSBM dalam kehidupan sosial ekomoni di Kromodangsan. Pemerintah memiliki peran penting sebagai pemberi dan stimulan. Selain itu, tanggapan masyarakat setelah mendengan WKSBM muncul tanggapan baik positif maupun negatif. Kebermanfaatan organisasi WKSBM menjadi pertimbangan beberapa pengurus dan masyarakat untuk mendukung organisasi ini.

Alfitri (2011, p. 204) mengatakan partisipasi masyarakat merupakan suatu alat guna memperoleh informasi mengenai kondisi, kebutuhan dan sikap masyarakat setempat yang tanpa kehadirannya program pembangunan serta proyek akan gagal". Selain dukungan dari pemerintah adanya faktor lain dari masyarakat umum yang belum bergabung menyatakan bahwa belum mengetahui sosialisasi WKSBM. Faktor ketidaktahuan masyarakat karena kurangnya sosialisasi menjadi penyebab kurang maksimalnya partisipasi masyarakat.

Pemerintah sebagai pihak ketiga dan juga sebagai mitra masyarakat memberikan dukungan dalam pengembangan WKSBM. Organisasi WKSBM "Kroda Mandiri" pernah mendapatkan dana stimulan sebagai wujud dukungan dari pemerintah. Melalui dana tersebut, diharapkan dapat membantu biaya operasional di awal pengembangan.

Nasdian (2014, pp. 110-113) mengatakan bahwa salah satu faktor yang mempengaruhi partisipasi masyarakat adalah kebijakan-kebijakan pemerintah terhadap komunitas. Penelitian ini kebijakan pemerintah merupakan faktor ekternal dalam pengembangan organisasi. Narasumber yang memiliki pengetahuan dan penyampaian yang menarik juga menjadi faktor ekternal. Selan dengan pendapat Bahransyaf, Tursilarini, \& Susmiyati (2011) dalam penelitiannya yang berjudul Penelitian Pengembangan Desa Beketahanan Sosial tentang pemberdayaan yang diberikan kepada anggota forum dengan konsep ketahanan 


\section{JPPM (Jurnal Pendidikan dan Pemberdayaan Masyarakat), 5 (1), 2018 - 71}

Shobichatul Aminah, Iis Prasetyo

pangan. Metode penyampaian materi, tanya jawab, dan stimulasi dalam penyuluhan.

Keterlibatan pemerintah juga diungkapkan oleh Remiswal (2013, p. 31) bahwa partisipasi merupakan kesediaan masyarakat secara sukarela untuk membantu kelangsungan program-program baik atas inisiatif lokal maupun pemerintahan. Pemerintah dalam hal ini memiliki tindakan untuk memberikan dana stimulan.

Hal ini diungkapkan oleh Alfitri (2011, p. 42) berkata dalam pengembangan masyarakat lokal di perdesaan, konsep partisipasi diartikan sebagai jaringan hubungan segitiga antara pemerintah daerah dan perusahaan dengan masyarakat." Pengembangan masyarakat melibatkan 3 pihak yaitu pemerintah, perusahaan dan masyarakat. Meskipun demikian, penelitian ini berfokus pada partisipasi masyarakat. Pemerintah dalam kegiatan WKSBM hanya sebagai sumber informasi selain memberikan dana stimulan.

Penelitian ini menunjukkan adanya komunikasi dalam pengembangan organisasi WKSBM. Tahap pengembangan organisasi perlu melakukan pengenalan organisasi ini kepada masyarakat. Sedangkan komunikasi yang dilakukan menggunakan narasumber seorang aktivis WKSBM. Kehadiran narasumber tersebut tidak hanya sekali namun berkelanjutkan. Penyampaian materi yang baik dan warga medapatkan kesempatan untuk bertanya.

Gagasan Greiner (Kusdi, 2011, p. 139) mengatakan bahwa "organisasi-organisasi pada umumnya mengalami suatu proses perkembangan sejalan dengan waktu dan bertambahnya ukuran organisasi itu sendiri". Faktor internal yang mempengaruhi dalam pengembangan organisasi WKSBM adalah faktor dari pengurus. Perkembangan organisasi WKSBM ditunjukkan dengan jumlah pengurus yang semakin banyak. Pada awal mulainya hanya memiliki satu yaitu ketua, kemudian berkembang menjadi depalan orang dan saat ini menjadi 12 pengurus WKSBM.

Berkembangnya organisasi yang ditandai dengan jumlah partisipasi tidak menutup kemungkanan bahwa terdapat kesulitan. Kesulitan untuk melaksanakan pertemuan menjadi penyebabnya. Pengurus memiliki kesibukan yang berbeda-beda sehingga sulit untuk melakukan pertemuan. Kesulitan untuk melaksanakan pertemuan menjadi faktor menurunya partisipasi masyarakat.

Faktor ekternal yang terakhir adalah kebermanfaatan WKSBM bagi masyarakat. Pada taham sosialisasi memberikan pengetahuan tentang WKSBM. Pengetahuan tentang WKSBM akan membuka wawasan masyarakat sehingga masyarakat tertarik dan ikut bergabung dalam kegiatan WKSBM. Manfaat secara berkelanjutkan adalah tersalurrnya dana dari donatur dan memberikan bantuan kepada penyandang masalah sosial.

\section{SIMPULAN}

Tahapan partisipasi masyarakat dalam pengembangan WKSBM melalui komunikasi multitrack terdiri dari tiga tahap partisipasi. Komunikasi pertama bertujuan sebagai bentuk rekruitmen pengurus. Komunikasi kedua bertujuan sebagai bentuk sosialisasi tujuan WKSBM kepada masyarakat. Kemudian, komunikasi ketiga adalah bentuk pelaksanaan kegiatan WKSBM. Setiap tahap komunikasi terdapat assesment atau penilaian, menyusun strategi dan desain, implementasi serta evaluasi komunikasi.

Bentuk-bentuk partisipasi masyarakat terdapat beberapa aspek yaitu; aspek kontribusi, tanggung jawab dan sikap. Pada aspek kontribusi terdapat empat bentuk kontribusi yaitu; kontribusi tenaga, dana, sarana dan pendapat. Tanggungjawab yang ditunjukkan oleh masyarakat sebagai pengurus sudah sesuai tugas dan peran masingmasing. Kemudian sikap masyarakat terhadap WKSBM terdapat sikap positif dan negatif.

Faktor yang mempengaruhi partisipasi masyarakat dibagi menjadi dua, yaitu; faktor internal dan eksternal. Faktor internal yang mempengaruhi partisipasi masyarakat adalah faktor usia, pekerjaan dan komunikasi. Sedangkan faktor ekternal adalah kebijakan pemerintah, tanggapan masyarakat dan kebermanfaatan WKSBM dalam kehidupan sosial ekomoni di Kromodangsan.

Bagi Pemerintah

Model komunikasi multitrack dapat digunakan sebagai komunikasi untuk 


\section{JPPM (Jurnal Pendidikan dan Pemberdayaan Masyarakat), 5 (1), 2018 - 72 \\ Shobichatul Aminah, Iis Prasetyo}

membentuk suatu organisasi sosial. Model komunikasi multitrack dapat dibuat sebagai petunjuk teknis dalam pembentukan organisasi.

Bagi WKSBM “Kroda Mandiri”

WKSBM “Kroda Mandiri” dapat melaksanakan kegiatan-kegiatan sosial dengan mengggunakan komunikasi multitrack. Adanya analisis terlebih dahulu dapat memudahkan suatu desain dan rencana kegiatan selanjutnya. WKSBM juga harus memantau dan mengevaluasi setiap kegiatan yang sudah terlaksana.

\section{DAFTAR PUSTAKA}

Adi, I. R. (2008). Pemikiran-pemikiran dalam pembangunan kesejahteraan sosial. Jakarta: Lembaga Penerbit, Fakultas Ekonomi, Universitas Indonesia.

Alfitri, A. (2011). Community development teori dan aplikasi. Yogyakarta: Pustaka Pelajar.

Anwas, O. M. (2013). Pemberdayaan masyarakat di era global. Bandung: Alfabeta.

Bahransyaf, D., Tursilarini, T. Y., \& Susmiyati, S. H. (2011). Penelitian pengembangan desa berketahanan sosial (Melalui pemberdayaan kelembagaan sosial lokal). New York, N.Y.: Libraries Unlimited.

Davis, K., \& Newstrom, J. W. (2012). Perilaku dalam organisasi (A. Dharma,). Jakarta: Erlangga.

Dinas Sosial Daerah Istimewa Yogyakarta. (2016). Isu strategis. Retrieved from http://dinsos.jogjaprov.go.id/isustrategis/

Djunaidi, G. M., \& Almanshur, F. (2012). Metodologi penelitian kualitatif. Yogyakarta: Arruzzubadia.

Hermawan, Y., \& Suryono, Y. (2016). Partisipasi masyarakat dalam penyelenggaraan program-program pusat kegiatan belajar masyarakat Ngudi Kapinteran. JPPM (Jurnal Pendidikan Dan Pemberdayaan Masyarakat), $\quad 3(1), \quad 97$. https://doi.org/10.21831/jppm.v3i1.8111

Huq, P. A. (1977). Leading to participatory local governance?: Participation, empowerment and community-driven development. University of South Australia.

Kusdi, K. (2011). Teori organisasi dan administrasi. Jakarta: Salemba Humanika.

Mukhtar, M. (2013). Metode praktis penelitian deskriptif kualitatif. Jakarta: GP Press Group.

Nasdian, F. T. (2014). Pengembangan masyarakat. Jakarta: Yayasan Pustaka Obor Indonesia.

Panasyuk, M. V, \& Nabiev, B. R. (2016). Regional social potential as the catalyst of diffusion of innovations. Journal of Organizational Culture, Communications and Conflict, 20, 20.

Prasetyo, G. B. (2015). Partisipasi sosial masyarakat dalam upaya pembangunan pariwisata desa bahasa (Studi di Desa Ngargogondo, Kecamatan Borobudur, Kabupaten Magelang). Jurnal Pendidikan Sosiologi Retrieved from http://journal.student.uny.ac.id/ojs/in dex.php/societas/article/viewFile/3773 13575

Ramachandran, V. (2003). Community participation and empowerment in primary education: Discussions of experiences from Rajasthan. New Delhi: SAGE Publications Ltd.

Ratna, N. K. (2010). Metodologi penelitian kajian budaya dan ilmu sosial humaniora pada umumnya. Yogyakarta: Pustaka Pelajar.

Remiswal, R. (2013). Menggugah partisipasi gender di lingkungan komunitas lokal. Yogyakarta: Graha Ilmu.

Rogers, E. M. (1976). Communication and development: The passing of the dominant paradigm. Communication Research, 3(2), 213-240.

Suroso, H., Hakim, A., \& Noor, I. (2014). 
JPPM (Jurnal Pendidikan dan Pemberdayaan Masyarakat), 5 (1), 2018 - 73

Shobichatul Aminah, Iis Prasetyo

Faktor-faktor yang mempengaruhi partisipasi masyarakat dalam perencanaan pembangunan di Desa Banjaran Kecamatan Driyorejo Kabupaten Gresik. WACANA, Jurnal
Sosial Dan Humaniora, 17(1), 7-15. Retrieved from http://wacana.ub.ac.id/index.php/wac ana/article/view/290 